\section{From Snowflakes} to Avalanche

\section{Meet Laura Purdie Salas, the Puzzle Poet}

\author{
SYLVIAVARDELL
}

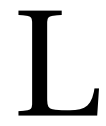

aura Purdie Salas grew up in Florida, currently lives in Minnesota, is a former teacher, and is now a prolific poet and frequent presenter with more than 130 books to her credit. She has authored both poetry and nonfiction, as well as resource books for educators and aspiring writers. Her work has been recognized with multiple awards, including selection as a National Council of Teachers of English (NCTE) Notable book, an International Literacy Association Teachers' Choice, and a Junior Library Guild Selection.

She has contributed to many educational series, including Capstone's Writer's Notebook books for young writers, and authored several books on getting published for aspiring authors. Her collection for teachers, 30 Painless Classroom Poems, includes a fun variety of approaches. She has published poems in multiple anthologies and authored these notable poetry books: Stampede! Poems to Celebrate the Wild Side of School!; BookSpeak!: Poems About Books; A Leaf Can Be ... , Water Can Be. .., A Rock Can Be. . . ; If You Were the Moon; and the rhyming Meet My Family! Animal Babies and Their Families.

She also has a multitude of resources available online, including an excellent website (LauraSalas.com), a lively blog (Writing the World for Kids), an e-newsletter for educators (Salas Snippets), videos, and downloadable materials.

With three new books of poetry debuting in 2019, Laura calls it her year of Poetry Palooza. She thrives on blending words and puzzles into poetry. Here, she talks with me about the roots of her love of poetry, her approach to writing, and her advice for educators and librarians.

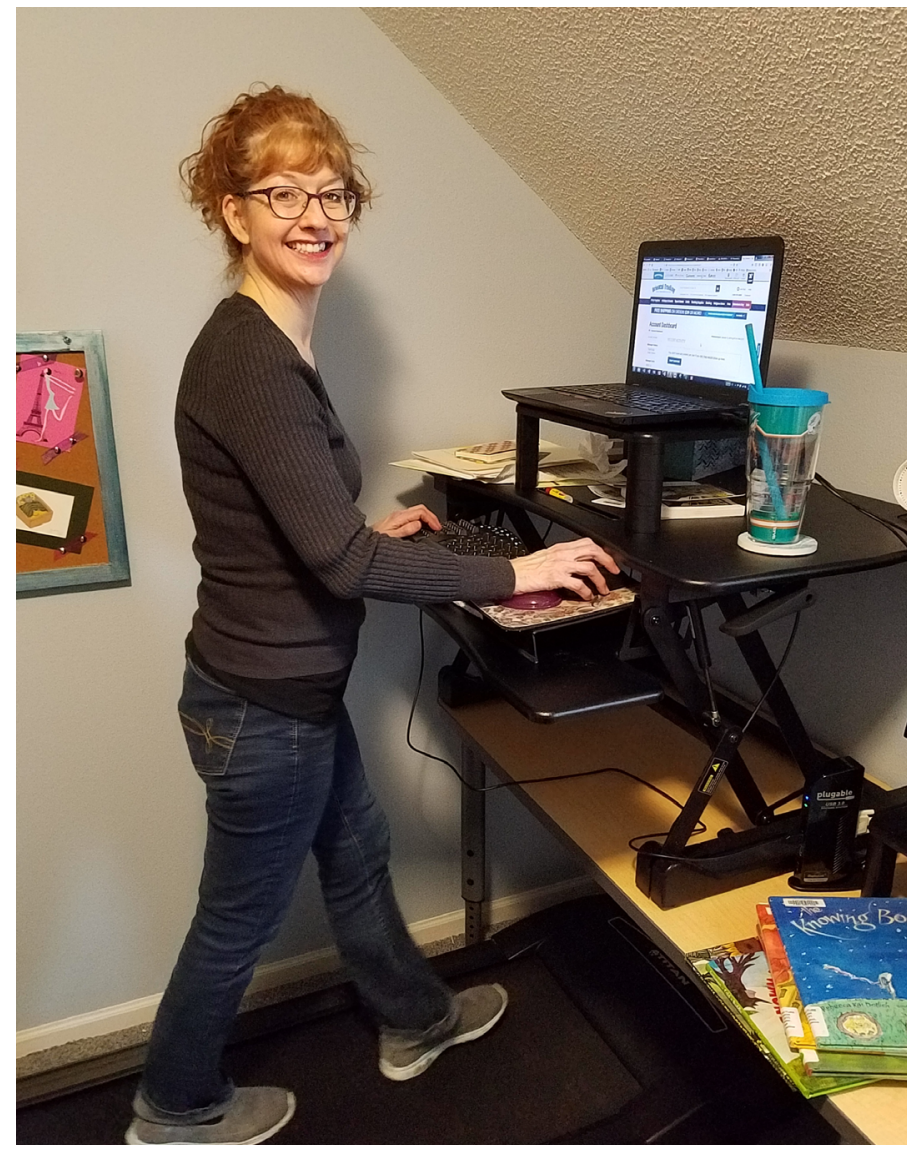

Laura Purdie Salas multitasks at her desk!

Q: Can you tell me about the roots of your love of poetry?

L: Growing up, my vast (ha!) poetry writing experience came in one fourth-grade poetry unit and one college class. In the mid-1990s, I heard poets Barbara Juster Esbensen and

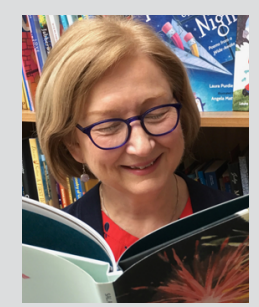

Sylvia Vardell is Professor in the School of Library and Information Studies at Texas Woman's University where she teaches graduate courses in literature for children and young adults. She is a recipient of the American Library Association's Scholastic Library Publishing Award and has authored several books on literature for children, including co-editing poetry anthologies with poet Janet Wong. She maintains the Poetry for Children blog, writes a poetry column for ALA's Book Links magazine, and has conducted presentations at state, regional, national, and international conferences. 

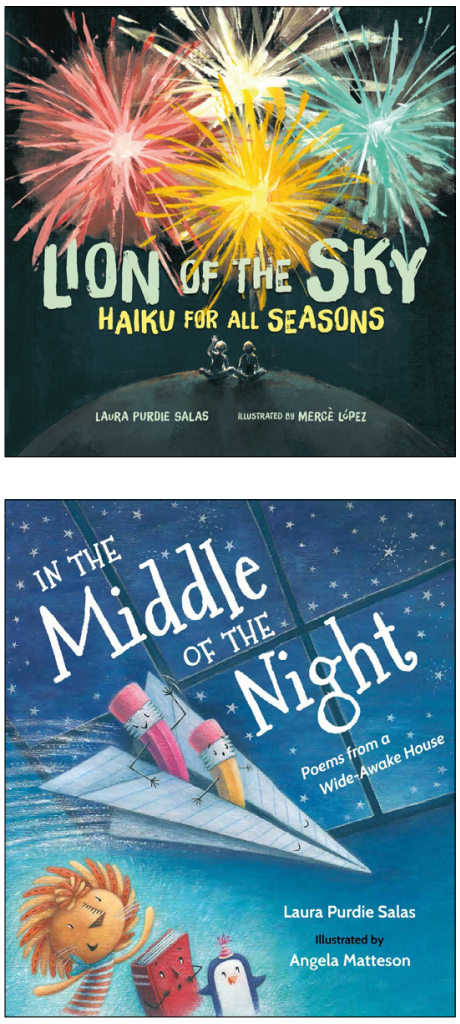

Sharon Chmielarz present. They were amazing, and I started reading children's poetry books.

A few years later, my writing mentor suggested I journal about our daughter's health issues. I grumbled but followed directions-and poetry came out! Terrible poetry. But those few poem snowflakes grew into an avalanche as I fell in love with writing poems.

Q: Much of your work blends poetry and nonfiction or moves between the two genres. Why do you think that is? What connections do you see?

L: Joyce Sidman's Song of the Water Boatman and Other Pond Poems blew my mind. So much of our world is categorized and classified that we sometimes miss opportunities to celebrate the overlap, the connections. Although I adore charts and lists and categories, I seem to write things that undermine them! Science poems celebrate our magnificent, messy world with clarity and precision. They make a fun entry point for nonscientific thinkers and offer deeper connections to scientifically minded readers.

Q: You clearly enjoy experimenting with the form and shape of poetry, even inventing your own form, the "riddle-ku." If you had to make a list of surefire poem forms that children should experience and enjoy, what would that include and why?

L: I do love it! I'll celebrate brevity here. For reading, here are what some favorite forms offer:

1. haiku—focus and mindfulness

2. things to do if ...-information and metaphor

3. poems for two voices-linking readers together

4. mask poems—empathy builder

5. list poems—unintimidating, sometimes surprising

6. ekphrastic poetry—response, emotion, connection

7. limericks-humor
8. riddle poems—puzzles, close reading

9. triolets or poems with refrains-repetition, oration, structure

10. odes-gratitude!

Q: You have created many resources to help educators and others introduce poetry to children, including books, newsletters, and teaching materials. For those hesitant to dip into poetry, how would you recommend they begin?

L: Well, you are my inspiration in that regard! Here are my basic tips for intimidated educators.

- Read anthologies (like your collaborations with Janet Wong!) that introduce many voices and styles.

- Read poetry often and out loud.

- Feel how you feel. It's okay to not like every poem!

- Let listeners respond to the poem honestly.

- Don't worry about having all the answers! It's better if you don't.

- Approach with joy! Ditch reverence. When you enjoy poetry, you'll grow poetry lovers all around you.

Q: Your work for aspiring writers-both children and adults-is also noteworthy. Do you think everyone can write poetry? Why should they try?

L: Yes, absolutely. Can everyone write amazing poetry? Maybe not. But I can't knit anything amazing, and I still love it. (I have gifted several scarves knitted with love and dropped stitches!) My poetry (even my terrible poetry) surprises me with my own thoughts and makes me think deeply. It also builds writing skills across all styles. (I highly recommend Amy Ludwig VanDerwater's Poems Are Teachers for educators.)

Q: I've been lucky enough to collaborate with you (along with poet Janet Wong) on several Poetry Friday anthologies, and you have such a knack for creating a beautiful poem even when given an assigned topic. You've written cinquain poems, acrostic poems, diamantes, found poems, and even shape poems. What is the secret to finding your focus or form for writing an assigned poem?

L: Thanks! My (ssh!) secret is trial and error. I just try one form after another. It's like shopping for pants. Too long. Too short. Um ... no. Just no. I can't tell which form fits until I try several on. I love playing with words, so it's fun! (Unlike pants shopping.) 
Q: What do you think librarians can uniquely offer when it comes to promoting poetry reading and writing?

L: I think librarians' biggest gift is presenting poetry in an anxiety-free atmosphere. Storytimes and book clubs, simple poetry stations, readings and slams ... A kid can just show up and discover the world, with no fear of judgment or bad grades. Bravo!

Q: This is clearly your Poetry Palooza year with three new poetry books being published. Congratulations! Can you give us some back story on how these books came to be?

L: Thank you! I'm thrilled! I wrote and sold them in different years, and each one is beautifully illustrated by a different genius.

Snowman - Cold = Puddle: Spring Equations: While brainstorming different nonfiction structures, I thought, "What about equations?” A migrating eagle's fish dinner became:

talons + pond $=$ fast food

And I got to pair the equations with science sidebars. What could be better?

In the Middle of the Night: Poems from a Wide-Awake House: Someone wrote a Fifteen Words or Less poem on my blog about chalk coming to life. I connected that with my "Lights Out at the Bookstore" poem in BookSpeak! Suddenly, I wondered what all our things do while we're asleep! From the garden hose to homework to library books, they are mostly up to fun and games. Although rocks ... well, here's my shortest poem in the book.

\section{Ready to Rock? No \\ End of day = time to play \\ But I admit: I like to sit}

Lion of the Sky: Haiku for All Seasons: For National Poetry Month in 2014, I created riddle-ku, a mash-up of riddle, haiku, and mask poems. I had so much fun with those (and they're still on my blog)! Writing a whole new book's worth to celebrate the seasons was a grand adventure. Here's a spring one:

twigs, sticks, mud, feathers-

I'm a closely woven home

for cheep-chirping chicks

Congratulations, Laura, on three new books out this yeareach unique and inviting. I can't wait to see what you puzzle through poetry next! \&
A Librarian Can Be ...

A librarian can be a...

B ook adorer.

C reative explorer.

D ue date extender.

E ndpaper mender.

F ast friend matcher.

$\mathbf{G}$ reat idea.

$\mathbf{H}$ atcher.

I nformagician. A

J oy, by definition.

K nowledge protector.

L ord of the projector!

M aker of readers,

$\mathbf{N}$ ice humans, good leaders.

O pportunity unlocker.

P lagiarism blocker.

Q uestioner. Why-er.

$\mathbf{R}$ eading inspirer.

S eeker of

T ech treasures.

U nwrapper of word pleasures.

V erifier of

W eird facts.

eX pert guide through the stacks. Whatever

Y ou need, this wizard will find. From A to

Z, a librarian will nurture your mind.

(C) Laura Purdie Salas, from The Heart of a Teacher 